\title{
Possibilities of iron elimination in aluminium alloys by vanadium
}

Dana Bolibruchová, Mária Žihalová

Department of Technological Engineering, Faculty of Mechanical Engineering, University of Žilina, Univerzitná 1,010 26 Žilina, Slovak Republic. danka.bolibruchova@fstroj.uniza.sk, maria.zihalova@fstroj.uniza.sk

Presence of iron is a common problem in Al-Si based alloys. Due to iron influence, mechanical and foundry properties of alloys are decreasing, so it is necessary to balance the influence in a certain way. One of possible solutions is addition of alloying elements, also called correctors of iron, into the melt. In this paper, the influence of vanadium on decreasing negative effect of iron in secondary alloy AlSi6Cu4 is assessed. In experimental part, properties of alloy with various addition of vanadium are evaluated. Microstructural and EDX analysis of selected structural parts are also a part of the experimental measurements. Based on statements from realised measurements can be stated that vanadium is an element, which can be used to correct negative effect of iron in secondary alloy AlSi6Cu4.

Keywords: AlSi6Cu4 alloy, correction of iron, vanadium, iron based phases.

\section{Acknowledgement}

This work was created in the framework of the grant project VEGA $N^{\circ} 1 / 0363 / 13$. The authors acknowledge the grant agency for support.

\section{References}

[1] BOLIBRUCHOVÁ, D., RICHTÁRECH, L. (2013). Study of the gas content in aluminium alloys. In: Manufacturing Technology, March 2013, Vol. 13, No. 1, pp. 14 - 20.

[2] TILlOVÁ, E., CHALUPOVÁ, M. (2009). Structural analysis of Al-Si cast alloys, pp. 191. EDIS, Žilina. ISBN 978-80-554-0088-4. (in Slovak)

[3] TAYLOR, J. A. (2004). The effect of iron in Al-Si casting alloys. In: 35th Australian Foundry Institute National Conference, Adelaide, South Australia, pp. 148 - 157.

[4] HURTAlOVÁ, L., TILlOVÁ, E. (2013). Elimination of the negative effect of Fe-rich intermetallic phases in secondary (recycled) aluminium cast alloy. In: Manufacturing Technology, March 2013, Vol. 13, No. 1, pp. 4450 .

[5] DINNIS, C. M., TAYLOR, J. A., DAHLE, A. K. (2005). As-cast morphology of iron-intermetallics in Al-Si foundry alloys. In: Scripta Materialia vol. 53, Issue 8, pp. 955 - 958.

[6] PETRÍK, J., HORVATH, M. (2011). The iron correctors in Al-Si alloys. In: Annals of Faculty Engineering Hunedoara - International Journal of Engineering, pp. 401 - 405. ISSN 1584-2673.

[7] SZARVASY, P., PETRÍK, J., ŠPEŤUCH, V. (2005). Use of iron correctors for improving properties of silumin castings. In: Slévárenství, Vol. 53, Issue 11-12, pp. 521 - 524. ISSN 0037-6825. (in Slovak)

[8] KUCHǍ̌, L., DRÁPALA, J. (2003). Binary systems of aluminium - admixture and their importance for metallurgy pp. 218. Delta Print, Děčín. ISBN 80-239-1469-3.

[9] PASTIRČÁK, R., URGELA, D., KRIVOŠ, E. (2012). Production of casting by paternless process. In: Archives of foundry engineering, Vol.12, Issue 1, pp. 87 - 92.

[10] ZHU, S., et al. (2013). Influences of Nickel and Vanadium Impurities on Microstructure of Aluminum Alloys. In: JOM, Vol. 65, Issue 5, pp. 584 - 592.

[11] Brůna, M., KUCHARĆÍK, L., SLÁDEK, A. (2013). Complex evaluation of porosity in A356 aluminium alloy using advanced porosity module. In: Manufacturing Technology, Vol. 13, No.1 pp.26-30.

[12] ŽIHALOVÁ, M. (2013). Elimination of Fe in secondary alloy AlSi6Cu4 by vanadium. Diploma thesis, pp. 60. (in Slovak) 